Research Papers

\title{
Nest Survival of American Coots Relative to Grazing, Burning, and Water Depths
}

\section{Survie au nid chez la Foulque d'Amérique en fonction du pâturage, du brûlage et de la profondeur d'eau}

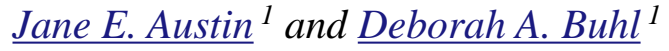

\begin{abstract}
Water and emergent vegetation are key features influencing nest site selection and success for many marsh-nesting waterbirds. Wetland management practices such as grazing, burning, and waterlevel manipulations directly affect these features and can influence nest survival. We used model selection and before-after-control-impact approaches to evaluate the effects of water depth and four common landmanagement practices or treatments, i.e., summer grazing, fall grazing, fall burning, and idle (no active treatment) on nest survival of American coots (Fulica americana) nesting at Grays Lake, a large montane wetland in southeast Idaho. The best model included the variables year $\times$ treatment, and quadratic functions of date, water depth, and nest age; height of vegetation at the nest did not improve the best model. However, results from the before-after-control-impact analysis indicate that management practices affected nest success via vegetation and involved interactions of hydrology, residual vegetation, and habitat composition. Nest success in idled fields changed little between pre- and post-treatment periods, whereas nest success declined in fields that were grazed or burned, with the most dramatic declines the year following treatments. The importance of water depth may be amplified in this wetland system because of rapid water-level withdrawal during the nesting season. Water and land-use values for area ranchers, management for nesting waterbirds, and long-term wetland function are important considerations in management of water levels and vegetation.
\end{abstract}

RÉSUMÉ. L'eau et la végétation émergente représentent des caractéristiques clés pour la sélection du site de nidification et le succès de reproduction chez de nombreux oiseaux de marais. Les pratiques d'aménagement des milieux humides, comme le pâturage, le brûlage et la gestion du niveau d'eau, affectent directement ces caractéristiques et peuvent donc avoir un effet sur la survie au nid. Nous avons utilisé la sélection de modèles et l'approche BACI (before-after control-impact) afin d'évaluer les effets du niveau d'eau et de quatre pratiques ou traitements courants d'aménagement, soit le pâturage estival ou automnal du bétail, le brûlage automnal et l'absence de traitement, sur la survie au nid de la Foulque d'Amérique (Fulica americana) nichant au lac Grays, un vaste milieu humide subalpin dans le sud-est de l'Idaho. Le meilleur modèle comportait les variables année $\times$ traitement et des fonctions quadratiques de la date, de la profondeur d'eau et de l'âge du nid; l'inclusion de la hauteur de la végétation autour du nid n'a pas permis d'améliorer le meilleur modèle. Toutefois, les résultats de l'analyse BACI ont indiqué que les pratiques d'aménagement affectaient la survie au nid en modifiant la végétation par le biais d'interactions entre l'hydrologie, la végétation résiduelle et la composition de l'habitat. La survie au nid dans les champs n'ayant pas été cultivés a peu changé entre les périodes pré- et post-traitements, tandis qu'elle a diminué dans les champs qui ont été broutés ou brûlés - les baisses les plus marquées advenant l'année suivant les traitements. L'importance de la profondeur d'eau dans ce milieu humide est peut-être amplifiée par le fait que le niveau d'eau diminue rapidement durant la saison de nidification. L'importance de l'eau et de l'utilisation du sol

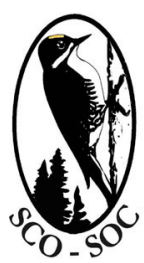

Sponsored by the Society of Canadian Ornithologists and Bird Studies Canada

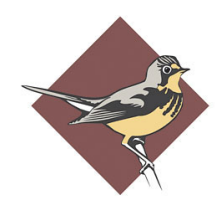


pour les propriétaires de ranch de la région, l'aménagement de l'habitat pour les oiseaux aquatiques nicheurs et le fonctionnement à long terme des milieux humides représentent des éléments essentiels à considérer dans la gestion des niveaux d'eau et de la végétation.

Key Words: American Coot; Fulica americana; grazing; hydrology; Idaho; nest survival; prescribed burning

\section{INTRODUCTION}

Water and emergent vegetation are key features influencing nest site selection and success for many marsh-nesting waterbirds that nest over water (e.g., Bouffard et al. 1987, Sutherland and Maher 1987, Forbes et al. 1989). For overwater nesting species, water surrounding the nest provides isolation from most mammalian predators. Greater water depths, and greater distances between a nest site and upland habitat, are more likely to limit ability of mammalian predators to detect and access nests, and hence should improve nesting success (Krapu et al. 1979, Sargeant and Arnold 1984, Jobin and Picman 1997, Albrecht et al. 2006; but see Brua 1999). Emergent vegetation, both residual and new growth, provides building material, structural support, protection from wind and waves, concealment from predators, and visual isolation of breeding pairs or nest parasites (Bouffard et al. 1987). Dense emergent vegetation, however, can hamper bird movements within the stand and thus limit bird use to the stand edges. Optimal nesting sites, therefore, are a balance between cover and isolation by water. American Coots (Fulica Americana) generally select nest sites that maximize distance to shore, i.e., isolation by water extent, and vegetation density and height; distance to shore is often positively related to water depth (Fredrickson 1970, Sutherland and Maher 1987).

Natural disturbances such as flooding, drought, and fire, and human disturbances such as livestock grazing, alter growth, density, and spatial distribution of wetland vegetation (Middleton 1998). Such disturbances open up wetlands that have dense emergent vegetation and stimulate new growth. Private landowners and public land managers may use various tools such as grazing, burning, herbicides, or altering water levels to manipulate wetland vegetation for desired outcomes (Kantrud 1985, Fredrickson and Lauban
1994). For example, managers may burn wetlands to reduce stem densities of coarse residual vegetation, increase nutrient turnover, increase certain aquatic invertebrate populations, or reduce undesirable plant species.

Many studies have evaluated the effects of management practices on duck nest success, although most studies focused on upland nesting habitats (reviewed by Kantrud 1985 and Bouffard et al. 1987; Gilbert et al. 1996). American Coots have rarely been the focus of such studies although they are often abundant and co-occur with breeding waterfowl. Coots select overwater nest sites associated with dense stands of emergent vegetation. Nest-building can be influenced by availability of residual vegetation for early nesters, and growth of new vegetation by later nesters (Fredrickson 1970). These aspects suggest that coots would be affected by management practices that affect water levels and emergent vegetation. Understanding how management practices affect nest success of coots provides opportunity for inferences for other overwater nesting species such as Redheads (Aythya americana) or grebes. Although many studies have reported nest success rates for coots (summary in Sutherland 1991; Gorenzel et al. 1982), few studies have evaluated factors influencing nest success or the impact of management practices on nest success, and results have been mixed (Gorenzel et al. 1982, Sutherland and Maher 1987, Sutherland 1991).

We conducted a study of waterbirds nesting on Grays Lake National Wildlife Refuge, a large, montane wetland in southeastern Idaho. The study was designed to quantify compatibility of specific management practices such as grazing with refuge objectives related to maintenance and productivity of nesting waterfowl and other waterbirds. The objective of this study was to evaluate effects of four common land-management practices or treatments, 
i.e., summer grazing, fall grazing, fall burning, and idle (no active treatment), on nest survival of waterbirds. These treatments represent commonly used practices on public and private lands in the region and result in different patterns of disturbance to the vegetation over a two-year period. We report here on the results for coots, the most abundant overwater nester. We hypothesized that active treatments would reduce residual vegetation available for nesting coots the following spring and thereby negatively affect coot nest survival. Biologists also had concerns regarding water withdrawals from the marsh during the breeding season, which affected extent and depth of wetland flooding. We hypothesized that greater water depths provide greater security from mammalian predation and therefore would be positively related to nest survival. A before-after-control-impact (BACI) design allowed us to examine treatment effects with anticipated annual variation in environmental conditions. We describe the seasonal hydrology of Grays Lake, examine factors affecting nest survival, and discuss management implications for vegetation and water-level management.

\section{STUDY AREA}

Grays Lake is a large (5620 ha) montane wetland (1946 m elevation) located in southeast Idaho, at the western edge of the Greater Yellowstone Ecosystem. The interior portion of the marsh is surrounded by a mosaic of semipermanently, seasonally, and temporarily flooded habitats, dominated by Baltic rush (Juncus balticus), tufted hairgrass (Descampia caespitosa), Kentucky bluegrass (Poa pratensis), brome (Bromus spp.), mat muhly (Muhlenbergia richardsonis), spikerush (Eleocharis spp.), and sedges (Carex spp.), with pockets of cattail (Typha spp.) and bulrush (Schoenoplectus spp.). Ranching (cattle, sheep, and hay production) has been the predominant land use in the valley since the late 1800s. During our study, cattle grazed upland and wetland areas from June through early November.

The water level of Grays Lake is determined primarily by surface run-off in spring, precipitation, and water-level management at two outflows. During spring, water from snowmelt and surrounding run-off results in water levels high enough to inundate wetland habitats surrounding the interior marsh. The system is typically drawn down to a standard level during late June-September to supply water for irrigation downstream, leaving surface water only in the interior marsh (Fig. 1). Only in very wet years is the summer water level at Grays Lake maintained such that standing water is available in the margins between the seasonally flooded Baltic rush-sedge habitats and the interior marsh.

Most of the interior marsh as well as some wetland habitats around its perimeter are contained within Grays Lake National Wildlife Refuge (GLNWR). The perimeter habitats are managed by GLNWR using grazing, fall burning, and haying; some fields are idled for one or several years. For our study, we used fields managed by GLNWR that were located around the perimeter of the contiguous interior marsh. Plant communities in each field ranged from dry upland grasslands to intermittently, seasonally, and semipermanently flooded wetlands (Austin et al. 2007a). For more extensive description of the study area, see Austin et al. (2002, 2007a).

\section{METHODS}

\section{Study design and habitat treatments}

We selected 12 of 15 fields controlled by U.S. Fish and Wildlife Service (USFWS) that were identified as perimeter wetland habitat, i.e., located along the edge of the interior marsh, for the study. Fields ranged in size from 21 to 121 ha (mean $=63 \mathrm{ha}$ ) and totaled 790 ha. We randomly assigned the 12 fields to one of four management treatments, with three replicates for each treatment. Treatment regimes were: (1) continuous idle (no active treatment; our control); (2) fall grazing of moderate intensity (SepOct, 1998-1999, 2.0-3.0 animal-unit months [AUM]/ha); (3) prescribed fall burning (Oct 1998) followed by two years of idle; and (4) summer grazing (Jul-Aug 1998, 0.8-1.2 AUM/ha) followed by two years of idle. All fields were left idle in 1996 through the nesting season in 1998 to allow vegetative structure and litter to become more similar among fields. We collected pre-treatment data in 1997 and 1998. Three fields were summer grazed during July-August 1998 and idled during 1999, and three fields were fall grazed during September-October 1998 and 1999. Three fields were burned in October 1998 and idled during 1999. The control fields received no treatments during 1997-1999. Fall burns, conducted over two days in 
Fig. 1. Seasonal changes in water levels recorded at Beavertail Point, Grays Lake, Idaho, for AprilOctober, 1997-2000, and 1979-2000, summarized into 10-day periods (box plots).

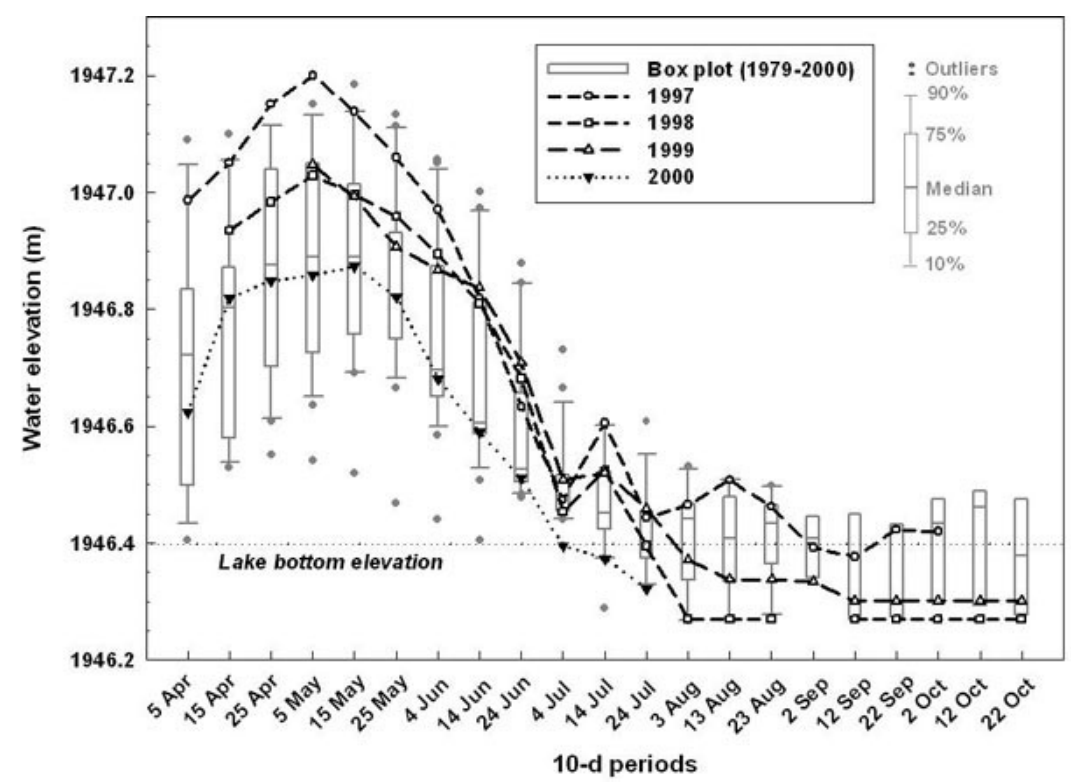

late October 1998, consumed most standing residual vegetation, with partial consumption of the litter layer on $85-98 \%$ of the area within each field. See Austin et al. (2007a) for further description of the impact of treatments on vegetation. We collected post-treatment data in 1999 and 2000. This BACI design allowed us to examine differences among management practices and between pre- and postapplication periods.

\section{Data collection}

We conducted systematic nest searches on each field at approximately 21-day intervals three times each year, beginning in the third week of May, first week of June, and last week of June. In 1999, four systematic searches were conducted within the same time frame. We searched for nests using a 30-m rope drag pulled between two people, hand-held poles to beat the vegetation, or, in areas that were dry or had shallow water, using a chain drag pulled between two all-terrain vehicles (Higgins et al. 1969). The complex topography of fields allowed us to search a range of wetland habitat types (Austin et al. 2002) and water depths up to $\sim 85 \mathrm{~cm}$ deep. Although areas searched for nests within each field included stands of cattail-bulrush, field boundaries and searches extended no more than $100 \mathrm{~m}$ into contiguous interior marsh, where management impacts were very limited.

Information recorded at nests followed procedures of Klett et al. (1986). All nests were checked every 10-21 days and their status monitored until terminated, i.e., hatched, destroyed, abandoned. At the first visit, we recorded type of nest-site vegetation (short $[<0.5 \mathrm{~m}]$, medium $[0.5-1.0 \mathrm{~m}]$, and tall $[>1.0 \mathrm{~m}]$ hydrophytes, and other). Information recorded during each visit included clutch size, incubation stage, and water depth at the nest $(\mathrm{cm})$. We estimated incubation stage of each egg in the nest using the flotation method (Westerskov 1950) and used the most advanced egg for incubation stage. A nest was considered hatched based on evidence at the nest (membrane adhering to eggshell fragments, presence of chick) that at least one egg hatched. It is important to note, however, that hatching of remaining eggs can be protracted because coots are asynchronous layers. Hence, our definition of a successful nest recognizes partial success rather than complete success, meaning all eggs in the clutch hatched. 


\section{Data analysis}

We examined the effects of date, nest age, water depth, year, nest vegetation type, and treatment on daily survival rate of coot nests. We estimated nest initiation date (nest age $=1$ ) by back-dating, based on a laying rate of one egg per day and a 23-day incubation period after the last egg was laid (Brisbin et al. 2002). We assumed the first egg laid was exposed for a total of 27 days, i.e., minimum number of exposure days for a successful nest. We excluded from analysis nests found already hatched or destroyed, nests abandoned or destroyed because of investigator disturbance, and nests that could not be relocated.

The first two years of the study were pre-treatment years and all fields were idled; however, we coded treatment for these years as the treatment that the field was assigned, rather than coding all fields as idle. We chose this analysis approach to allow examination of trends of the different treatment assignments across all 4 years, and in recognition that treatments differed between the third and fourth years; summer-grazed and fall-burned fields were treated then idled, whereas fall-grazed field were grazed both post-treatment years.

We usually measured water depth at every nest visit; however, there were 33 nests for which water depth was not always or ever measured. For nests that had at least one water depth measurement, we estimated missing water depth values one of two ways: (1) we estimated water depth from a linear regression fit between date and the other measurements for that nest, or (2) if we were not able to fit a regression for a nest, i.e., only one water depth measurement, then we used a common slope computed from a linear regression of all nests in that field that year and an intercept computed using this slope and the one existing measurement on that nest. We excluded seven nests from analysis that had no water depth measurements. All nests but one were defined as being in emergent hydrophytes; we excluded the single nest not in emergent hydrophytes. Nest vegetation type for nests remaining in the analyses therefore became a categorical variable of vegetation height at the first visit.

To account for the anticipated effects of nest age and nest initiation date (Grant et al. 2006, Pieron and Rohwer 2010, Arnold 2011), we first examined the relationship between daily survival rate (DSR) and date and age of the nest using logistic-exposure methods (Shaffer 2004). We treated each interval between visits to a nest as an observation in the analysis. The response variable was whether the nest survived or failed during the interval. For each observation, we computed nest age (days) and date (Julian date) as the age or date at the midpoint of the interval (IAGE AND IDATE, respectively). We constructed a candidate set of models with the variables IAGE, IAGE ${ }^{2}$, IDATE, and IDATE ${ }^{2}$. All possible models including these variables were constructed; however, a quadratic term for a variable was not included in a model without also including the linear term for that variable. We also included the null model in the candidate set, for a total of nine models considered. Each candidate model was fit using the GENMOD procedure of SAS (SAS Institute Inc. 2007). We evaluated candidate models using Akaike's Information Criterion (AIC; Burnham and Anderson 2002).

We then assessed the effects of water depth (WDEPTH), nest vegetation height (NESTVEG), and year $x$ treatment combination on DSRs by adding these variables to the model with the lowest AIC value of the age-date models. We used the water and nest vegetation data for the beginning of each interval. We created a candidate set of models by including all possible models with these three variables and including the variables from the best age-date model in all models. We fit each candidate model using the GENMOD procedure of SAS (SAS Institute Inc. 2007) and evaluated them using Akaike's Information Criterion (AIC; Burnham and Anderson 2002). We used graphical methods (Shaffer and Thompson 2007) to examine the fit of the "best" model. Observations were grouped into discrete categories based on the explanatory variable being examined and daily survival rate estimated for each category. We then plotted these DSR estimates against the explanatory variable, overlaid with a plot of the explanatory variable versus the predicted values from the best model, and visually examined model fit. We used the best model, i.e., model with the lowest AIC value, from this final analysis to estimate nest success or DSR rate as a function of selected explanatory variables included in this model, while holding other variables at their median values.

To specifically examine treatment effects, we compared the average DSR of nests for the two pretreatment years (1997 and 1998) to the average daily 
Table 1. Number of American Coot (Fulica Americana) nests, by year and treatment, used in analysis of nest survival at Grays Lake, Idaho, 1997-2000.

\begin{tabular}{cccccc}
\hline \hline Year & Idle & Fall grazed & Fall burned & Summer grazed & All \\
\hline 1997 & 13 & 37 & 25 & 13 & 88 \\
1998 & 37 & 58 & 28 & 64 & 187 \\
1999 & 96 & 95 & 126 & 73 & 390 \\
2000 & 56 & 59 & 60 & 52 & 227 \\
All & 202 & 249 & 239 & 202 & 892 \\
\hline
\end{tabular}

survival rate for the two post-treatment years (1999 and 2000) for each treatment separately, using leastsignificant difference contrasts (SAS Institute Inc. 2007). We similarly conducted pair-wise contrasts among treatments in 2000.

\section{RESULTS}

We located 997 coot nests during the study and were able to include a total of 892 nests in the analyses (Table 1). Most (72\%) nests hatched, $25 \%$ were destroyed by predators and the remaining nests were abandoned, destroyed by weather, or destroyed by livestock ( $\leq 1 \%$ each). Summary statistics for explanatory variables used in the analyses are presented in Table 2. Of the nine candidate models including only age and date variables, the model with IAGE, IAGE ${ }^{2}$, IDATE, and IDATE ${ }^{2}$ was the most probable model $(w>0.99$; Table 3$)$ explaining DSRs. The null model ranked last. When we then added the explanatory variables WDEPTH, NESTVEG, and year $\times$ treatment to this model, the top model included WDEPTH and year $\times$ treatment and had an Akaike weight of 0.75; the next best model included NESTVEG along with these variables, and had a $\triangle \mathrm{AIC}$ value of 2.3 and a weight of 0.25 . The top model fit well for age and date but fit poorly for WDEPTH; the plots showed that the relationship between WDEPTH and daily survival rate appeared to be curvilinear rather than linear. Therefore, we added a squared term for WDEPTH as an explanatory variable and reran the analysis. In the final candidate set of models, the top model included the variables year $\times$ treatment, WDEPTH, and WDEPTH ${ }^{2}$, along with the IAGE, IAGE ${ }^{2}$, IDATE, and IDATE ${ }^{2}$ variables (Table 3 ). The next best model was similar but excluded WDEPTH ${ }^{2}$. Nest vegetation was included in the third best model but added relatively little explanatory value compared to the top model. All other models had $\Delta$ AIC scores $>4$. Visual assessment of the top model revealed that the model fit well for all variables included. We reran the analysis including field as a random block to verify these results and found no change in either initial or final model results.

We graphed DSR or nest success as a function of the explanatory variables, IAGE, IDATE, and WDEPTH. DSRs quickly increased to an asymptote for nests $>10$ days old (Fig. 2). DSRs were highest during the middle period of the nesting season (approximately 27 May-14 June) then declined during the last 1-20 days of nesting (Fig. 3). Nest success rates increased with water depth up to a peak of 0.53 for water depths of $54-62 \mathrm{~cm}$ then declined at greater depths (Fig. 4).

We estimated nest success for each year $\times$ treatment combination, computed using the middle period of nest initiation (27 May; Julian date 147) and median water depth (31 cm; Fig. 5). Estimates of nest success for other dates or water depths yielded very similar patterns. Nest success varied substantially between treatments in both pre-treatment years, with highest nest success in fields assigned to summer- and fall-grazing treatments. Nest success fell markedly from 1998 to 2000 in all except the idled fields, and in 1999 nest success rates for all treatments converged at $0.28-0.33$. 
Fig. 2. Daily survival rate (DSR), and $95 \%$ confidence interval, as a function of nest age, averaged across all year by treatment combinations for nests on date 165 and median water depth of 31, for American Coot (Fulica Americana) nests at Grays Lake, Idaho during 1997-2000.

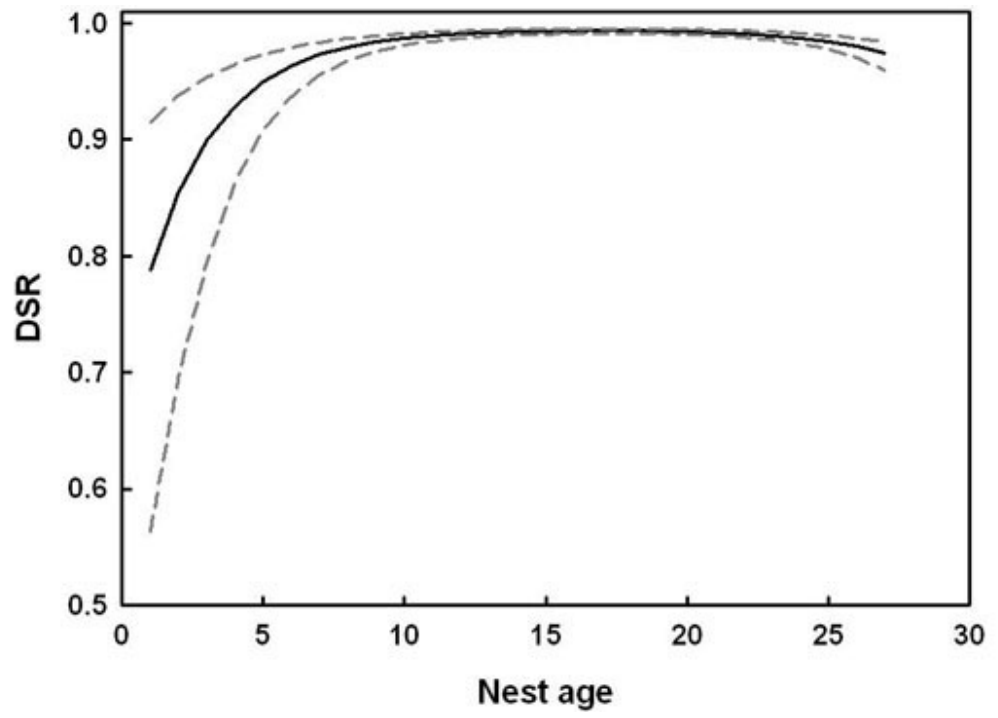

DSRs in idled fields did not differ between pre- and post-treatment years $\left(\chi^{2}=0.01, P=0.920\right)$. Average DSRs in the post-treatment years were lower than in pre-treatment years for fall-grazed $\left(\chi^{2}=17.00, P\right.$ $<0.001)$ and summer-grazed $\left(\chi^{2}=11.40, P<0.001\right)$ fields and tended to be lower in fall-burned fields $\left(\chi^{2}=3.42, P=0.064\right)$. By 2000 , DSR of coot nests in idled fields was higher than in fall-grazed $\left(\chi^{2}=\right.$ 6.93, $P=0.008)$ and summer-grazed fields $\left(\chi^{2}=\right.$ 4.05, $P=0.004)$; all other pair-wise comparisons were nonsignificant $(P>0.05)$.

\section{DISCUSSION}

Previous studies comparing water depth at the nest between successful and unsuccessful nests reported no effect (Gorenzel et al. 1982) or a positive relation with nest success only when considered as pair success (first and renests combined; Sutherland 1991). Studies of overwater nesting diving ducks provided similarly mixed results (summarized in Brua 1999). Our data showed a strong positive relationship between water depths and nest success. Nest losses were largely attributed to predation, but declining water levels may have caused nest abandonment (Joyner 1977, Lindvall and Low
1982, Gorenzel et al. 1982) with subsequent predation. With declining water levels later in the season, nests also may be lost because of toppling, as they lose structural stability. We speculate that the decline in nest success at water depths greater than about $60 \mathrm{~cm}$ also relates to the stability of the nest foundation; at such depths, vegetation may not be robust enough to support the nest, particularly if subjected to wind or wave action or if water levels rapidly drop (Wolf 1955).

Water levels in unmodified wetlands usually decline slowly over the breeding season because of seasonality of water input, i.e., early spring flooding, and evapotranspiration. American Coots at Grays Lake, however, experience rapidly changing water and vegetation conditions during their nesting period. Spring flooding in most years results in extensive flooding of perimeter habitats during late April and early May. Water levels peak in early May and then are drawn down to a prescribed level by late June; the most rapid decline usually occurs in June (Fig. 1). This period of drawdown coincides with the main nesting period for coots and other nesting waterbirds (Austin and Pyle 2004). Growth of emergent vegetation begins in early May and robust emergents such as cattail can 
Table 2. Summary statistics of explanatory variables and other selected variables for American Coot (Fulica Americana) nests at Grays Lake, Idaho, 1997-2000. Dates given are Julian dates.

\begin{tabular}{lccccc}
\hline \hline Variable & $\mathrm{N}^{\dagger}$ & Mean & Median & Minimum & Maximum \\
\hline IAGE & 1303 & 19.5 & 20.5 & 4.5 & 30.0 \\
IDATE & 1303 & 166.0 & 166.5 & 133.5 & 195.0 \\
WDEPTH & 1303 & 32.3 & 31.0 & 0 & 90.0 \\
Initiation date & 892 & 147.3 & 147.0 & 121.0 & 177.0 \\
Interval length & 1303 & 10.3 & 11.0 & 1.0 & 27.0 \\
\hline
\end{tabular}

$\dagger$ For initiation date, sample size is the number of nests; for all other variables, sample size is the number of visitation intervals.

reach $>60 \mathrm{~cm}$ in height by late May. It is not surprising, then, that the best model for coot nest survival included quadratic functions of date and water depth. Nest survival was optimal during the middle period of nesting (approximately 27 May to mid-June), when cover from new emergent vegetation was high, and declined after about 19 June as water depths approached the summer low and extent of surface flooding shrank. DSRs during this middle period are similar to survival rate estimates summarized in Brisbin et al. (2002; 0.9895-0.9936).

The addition of the nest vegetation variable did not improve the best model. Nest losses were highest during the first 10 days of exposure, when the nest vegetation height, recorded only when the nest was found, would have been most representative of vegetative conditions. This variable likely was too coarse a measure to contribute to explanation of nest survival rates, as the three vegetation height categories were quite broad (0.5-m increments). This categorical measure does roughly represent shorter, e.g., sedges or Baltic rush, versus taller, e.g., cattail or bulrush, emergent cover, which have achieved most of their growth by the time coots initiate nesting (J. E. Austin, unpublished data). However, this variable provides no indication of vegetation density or patchiness, which would be important in obscuring a nest from predators or providing stable anchoring material. Further investigations would be valuable to evaluate the relative influences of water depth, vegetation height, density, and patchiness, and distance to edge on nest survival, similar to studies that have evaluated such metrics for nest site selection (Gorenzel et al. 1982, Sutherland and Maher 1987, Alisauskas and Arnold 1994).

The main objective of this study was to investigate the impact of grazing and burning on nest survival of coots. The BACI design allowed us to evaluate effects of management treatments in the face of substantial changes in environmental conditions. The results supported our original hypothesis that active treatments would negatively affect coot nest success. Nest success in idled fields changed little between pre- and post-treatment periods, whereas it declined in fields that were grazed or burned. The drop in nest success was most dramatic the year following treatments. The inclusion of year $x$ treatment interactions in the model and the BACI results indicate that these management practices did impact nesting via altered vegetation conditions, and involved interactions of hydrology, residual vegetation, and habitat composition. That management treatments negatively impacted vegetation and hence nesting opportunities for coots is further supported by results from a concurrent study on the plant community (Austin et al. 2007a). 
Table 3. Log likelihood (LL), number of parameters (K), AIC, $\Delta$ AIC, and Akaike weight (w) for the top three models of the initial and final analyses of American Coot (Fulica Americana) nest survival at Grays Lake, Idaho, 1997-2000. The initial candidate set of models included age (IAGE) and date (IDATE) and their quadratic functions; the final candidate set of models included age, date, water depth (WDEPTH), nest vegetation (NESTVEG), and year $x$ treatment (YEAR $\times$ TRT) variables, including the quadratic terms for age, date, and water depth. Effective sample size was 11,081.

\begin{tabular}{|c|c|c|c|c|c|}
\hline Models & LL & $\mathrm{K}$ & AIC & $\Delta \mathrm{AIC}$ & $w$ \\
\hline \multicolumn{6}{|l|}{ Initial candidate set of models } \\
\hline Global model: IAGE, IAGE², IDATE, IDATE² & -609.2 & 5 & 1228.5 & 0 & $>0.99$ \\
\hline IAGE, IAGE ${ }^{2}$, IDATE & -618.2 & 4 & 1244.4 & 15.9 & $<0.01$ \\
\hline IAGE, IAGE ${ }^{2}$ & -632.0 & 3 & 1270.0 & 41.5 & $<0.01$ \\
\hline \multicolumn{6}{|l|}{ Final candidate set of models } \\
\hline $\begin{array}{l}\text { IAGE, } \mathrm{IAGE}^{2}, \mathrm{IDATE} \text { IDATE} \\
\mathrm{WDEPTH}^{2}\end{array}$ & -548.8 & 22 & 1141.6 & 0 & 0.58 \\
\hline IAGE, IAGE ${ }^{2}$, IDATE IDATE ${ }^{2}, \mathrm{YEAR} \times \mathrm{TRT}, \mathrm{WDEPTH}$ & -550.8 & 21 & 1143.7 & 2.0 & 0.21 \\
\hline $\begin{array}{l}\text { Global model: IAGE, IAGE }{ }^{2} \text {, IDATE, IDATE², } \\
\text { YEAR } \times \text { TRT, WDEPTH, WDEPTH }{ }^{2}, \text { NESTVEG }^{2}\end{array}$ & -548.2 & 24 & 1144.5 & 2.9 & 0.14 \\
\hline
\end{tabular}

That study found that plant biomass in the wettest cover types, i.e., cattail, bulrush, and spikerush communities that occurred in the deeper wetland zones within the fields, and the most likely coot nest sites, experienced greater negative impacts from fall burning and summer grazing than under the idle treatment.

By random assignment, fields assigned to the continuous idle treatment contained proportionally twice as much semipermanent wetland habitat as fields assigned to other treatments (21.3 vs. 5.4-9.8\%). Extremely high water levels in 1997 were $0.65 \mathrm{~m}$ higher in early May than in 1998 and 1999, and remained $>0.25 \mathrm{~m}$ higher through the median nest initiation date for coots. The 1997 water levels submerged much of the residual vegetation in semipermanent habitat and likely pushed coots to nest in habitats dominated by less robust residual or emergent vegetation, such as grasses and sedges, with which to construct nest platforms. By 2000, however, the semipermanent habitat likely provided the only emergent habitat that retained water into the latter half of the nesting period, and likely provided the more attractive and secure habitat for nesting coots. Indeed, in 2000 , most coot nests were found in semipermanently flooded habitat, often along the edge of the interior marsh (W. Smith, personal communication).

Patterns of water levels during the nesting period were similar between 1998 and 1999, but grazing and burning treatments applied in late summer and fall 1998 removed standing vegetation (Austin et al. 2002) and reduced plant growth (Austin et al. 2007a). Damage to cattail stems by active treatments also may have contributed to reduced growth the following spring by reducing oxygen transfer to the rhizomes (Jordan and Whigham 1988). Hence, coots nesting in 1999 encountered above-average water levels but much less residual material with which to construct nest platforms, and likely also reduced growth of some robust emergents like cattail. Early nesters may have been 
Fig. 3. Daily survival rate (DSR), and $95 \%$ confidence interval, as a function of date, averaged across all year by treatment combinations for nests 14 days of age and median water depth of $31 \mathrm{~cm}$, for American Coot (Fulica Americana) nests at Grays Lake, Idaho during 1997-2000.

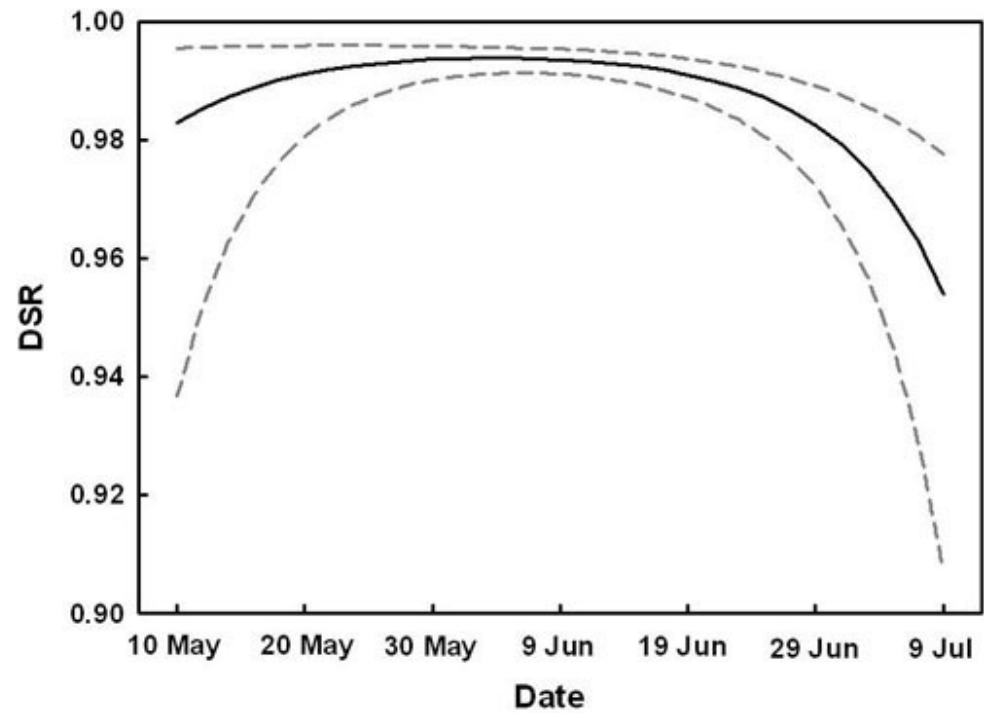

forced to build poorer nest platforms and in shallower sites, and with less concealment from residual material. Nest success in 1999 declined in all but the continuously idled fields. The importance of residual vegetation to coot nesting also was indicated by the 12 to 14 day delay in median nest initiation date compared with other years (30 May vs. 16-18 May for all nests found; Austin and Pyle 2004). Weather was an unlikely contributor in this delay, as average May temperatures were similar between 1998 and 1999. Only Canada geese, which also heavily rely on residual vegetation for nesting, showed a similar delay in nesting in 1999 (Austin and Pyle 2004). Coots will delay nesting when residual vegetation is poor, waiting for growth of new vegetation to provide substrate for nests (Weller and Spatcher 1965, Fredrickson 1970, Gorenzel et al. 1981). Delayed nesting could have made later nests more susceptible to predation during the rapidly declining water levels of mid-late June.

In 2000, water levels during the nesting season followed long-term averages but ended lower than average by late June. Spring surface flooding was much less extensive than in previous years and water rapidly retreated to deeper marsh zones near the interior. This resulted in a much greater area of the basin, including Baltic rush and some cattailbulrush habitats, that could be accessed by mammalian predators during the nesting period. Indeed, we found their sign much farther into the marsh that year than in previous years. Nest success in idled fields remained similar to earlier years, but was higher than nest success in fall- and summergrazed fields; nest success in fall-burned fields was at intermediate levels. Despite one year of rest for fields that had been grazed during summer 1998, fall and summer grazing treatments had similarly low levels of nest success in 2000.

The strong relationship between nest survival and water depth suggests mammalian predators are more important than avian predators in this system. Most common at Grays Lake were red fox (Vulpes vulpes), striped skunk (Mephitis mephitis), American Crows (Corvus brachyrhynchos), and Common Ravens (C. corax); also present were mink (Mustela vison), coyotes (Canis latrans), raccoons (Procyon lotor), Black-billed Magpie (Pica hudsonia), and Northern Harrier (Circus cyaneus; Austin et al. 2002). Nest concealment by residual 
Fig. 4. Nest success rate by water depth, averaged across all year by treatment combination, for nests initiated at median initiation date of 27 May, for American Coot (Fulica Americana) nests at Grays Lake, Idaho during 1997-2000. Nest success rate was a model estimate based on a 27-day exposure period.

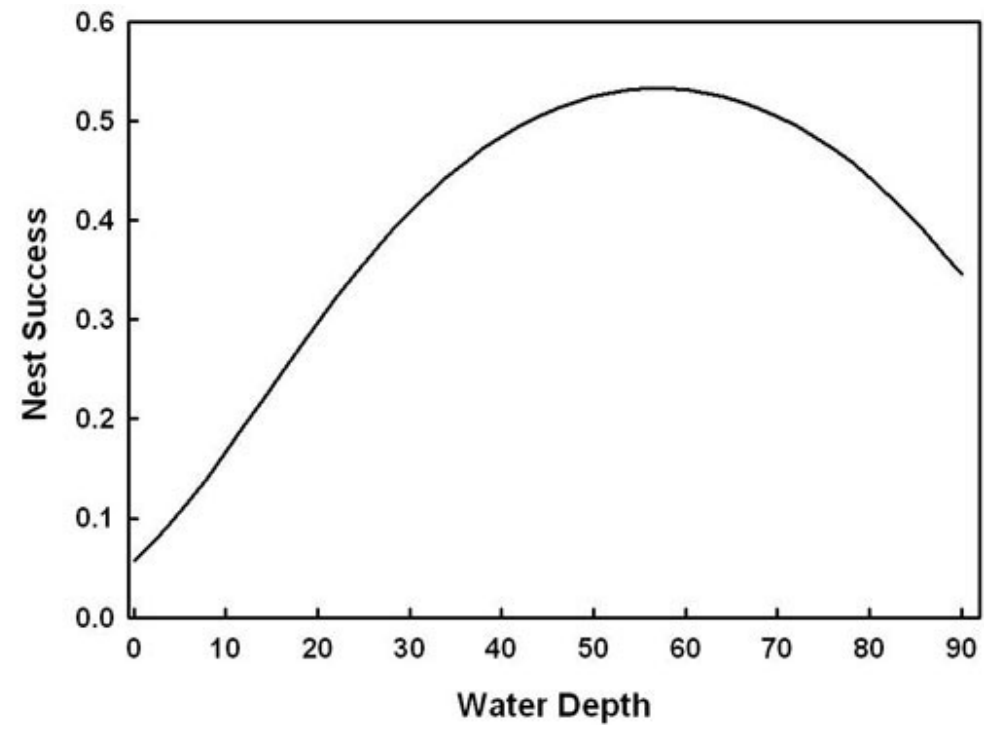

or new vegetative growth is probably less important to nest success in habitats where mammalian predators predominate over avian predators (Clark and Nudds 1991, Maxson and Riggs 1996). Selecting secure nesting sites may be further complicated by the diversity of nest predators present (Brua 1999) and rapidly declining water levels.

Increased densities of breeding coots also may have contributed to the consistent pattern of declining nest success between 1998 and 1999 through additional territorial strife and nest parasitism (Brisbin et al. 2002). We estimated density of breeding coots by conducting line-transect surveys through each of the fields each May-June as part of the larger study (Austin et al. 2002). Densities of breeding coot pairs (no./100 ha) on all 12 fields more than doubled between 1998 to 1999 then declined in $2000(1997=22.5,1998=25.3,1999=59.2$, $2000=26.2$ ). Coot densities were $1.3-7.8$ times higher in 1998 than in 1999, and were 2.7 - 4.3 times higher in idled fields. However, unit and year were the only factors influencing coot densities; treatment type did not occur in the models best supported by the data (Austin et al. 2002). Nest success continued to decline in all actively treated fields in 2000, when coot densities returned to previous levels, but remained similar to previous levels in idled fields.

\section{CONCLUSIONS}

Our BACI experiment showed that water depth and manipulation of residual vegetation by burning and grazing influenced the nesting success of American Coots at Grays Lake. Water depth also was found to be an important factor influencing nest survival of the earlier nesting species at Grays Lake, Sandhill Cranes (Grus canadensis; Austin et al. 2007b) and Canada geese (Branta canadensis; Austin et al. 2002). The importance of water depth may be amplified in this system because of rapid waterlevel declines during the nesting season. Delaying or slowing the rate of water withdrawal during the waterbird nesting season would likely benefit a wide variety of waterbird species that nest there (Austin et al. 2002). However, drawing Grays Lake down each spring also provides important summer and fall 
Fig. 5. Nest success rate for each year and treatment combination, for nest initiation date of 27 May and median water depth of $31 \mathrm{~cm}$, for American Coot (Fulica Americana) nests at Grays Lake, Idaho during 1997-2000. Nest success rate was a model estimate based on a 27-day exposure period.

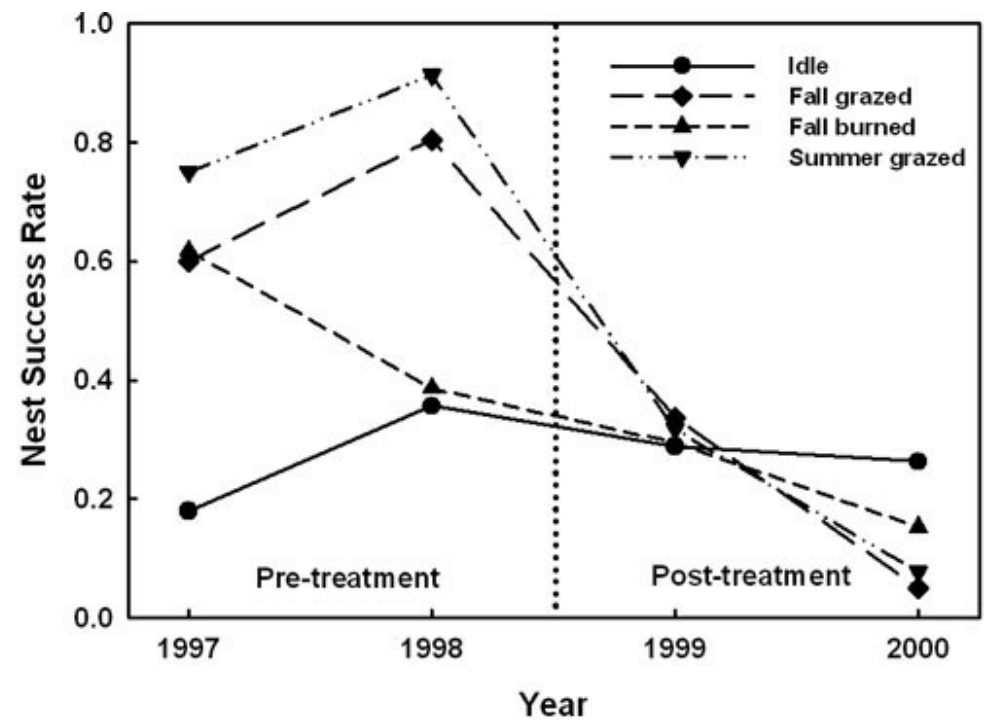

forage for cattle in wetland habitats. These wetland habitats are highly valued by private ranchers for their productivity. Therefore, changing the marsh's water management would benefit from the involvement of multiple federal, state, and private landowners, and consideration of balancing among water and land-use values for area ranchers, management for nesting waterbirds, and long-term wetland function.

Responses to this article can be read online at: http://www.ace-eco.org/vol6/iss2/artl/responses/

\section{Acknowledgments:}

This study was a cooperative effort between the $U$. S. Fish and Wildlife Service's Grays Lake National Wildlife Refuge and U.S. Geological Survey's Northern Prairie Wildlife Research Center. Funding was provided through the U.S. Geological Survey's Quick Response Program with in-kind support provided by the refuge. Any use of trade, product, or firm names is for descriptive purposes only and does not imply endorsement by the U.S. Government. We thank Refuge Manager M. Fisher for his support during all phases of this study. A. Henry provided valuable assistance in preparing data for analysis. We thank A. R. Henry, C. D. Mitchell, T. Arnold, W. Reed, W. Smith, and an anonymous reviewer for their comments on earlier versions of this manuscript.

\section{LITERATURE CITED}

Albrecht, T., D. Horák, J. Kreisinger, K. Weidinger, P. Klvana, and T. C. Michot. 2006. Factors determining Pochard nest predation along a wetland gradient. Journal of Wildlife Management 70:784-791. http://dx.doi.org/10.2193/0022-541X(2006) 70[784:FDPNPA]2.0.CO;2

Alisauskas, R. T., and T. W. Arnold. 1994. American Coot. Pages 127-143 in T. C. Tacha and C. E. Braun, editors. Migratory shore and upland game bird management in North America. International Association of Fish and Wildlife Agencies, Washington, D.C., USA.

Arnold, T. W. 2011. Onset of incubation and patterns of hatching in the American Coot. Condor 
113:107-118. http://dx.doi.org/10.1525/cond.2011. 100001

Austin, J. E., A. R. Henry, and I. J. Ball. $2007 b$. Sandhill Crane abundance and nesting ecology at Grays Lake, Idaho. Journal of Wildlife Management 71:1067-1079. http://dx.doi.org/10.2193/2005-705

Austin, J. E., J. R. Keough, and W. H. Pyle. $2007 a$. Effects of habitat management treatments on plant community and biomass in a montane wetland. Wetlands 27:570-587. http://dx.doi.org/10.1672/02 77-5212(2007)27[570:EOHMTO]2.0.CO;2

Austin, J. E., and W. H. Pyle. 2004. Nesting ecology of waterbirds at Grays Lake, Idaho. Western North American Naturalist 63:277-292.

Austin, J. E., W. H. Pyle, J. R. Keough, and D. H. Johnson. 2002. Evaluation of management practices in wetland meadows at Grays Lake National Wildlife Refuge, Idaho, 1997-2000. Final Report to U.S. Fish and Wildlife Service, Region 1. U.S. Geological Survey, Northern Prairie Wildlife Research Center, Jamestown, North Dakota, USA.

Bouffard, S. H., D. E. Sharp, and C. E. Evans. 1987. Overwater nesting by ducks: a review and management implications. Pages 153-158 in Great Plains Wildlife Damage Control Workshop Proceedings. University of Nebraska, Lincoln, Nebraska, USA. [online] URL: http://digitalcommo ns.unl.edu/gpwdcwp/52/

Brisbin, Jr., I. Lehr, and T. B. Mowbray. 2002. American Coot (Fulica americana). In A. Poole, editor. The birds of North America online. Cornell Lab of Ornithology, Ithaca, New York, USA. [online] URL: http://bna.birds.cornell.edu/bna/spec ies/697a

Brua, R. B. 1999. Ruddy Duck nesting success: do nest characteristics deter nest predators? Condor 101:867-870. http://dx.doi.org/10.2307/1370078

Burnham, K. P., and D. R. Anderson. 2002. Model selection and multimodel inference: a practical information-theoretic approach. Second edition. Springer-Verlag, New York, New York, USA.

Clark, R. G., and T. D. Nudds. 1991. Habitat patch size and duck nesting success: the crucial experiments have not been performed. Wildlife Society Bulletin 19:534-543.

Forbes, M. R. L., H. P. Barkhouse, and P. C. Smith. 1989. Nest-site selection by Pied-Billed Grebes Podilymbus podiceps. Ornis Scandinavica 20:211-218. http://dx.doi.org/10.2307/3676915

Fredrickson, L. H. 1970. Breeding biology of American Coots in Iowa. Wilson Bulletin 82:445-458.

Fredrickson, L. H., and M. K. Lauban. 1994. Managing wetlands for wildlife. Pages 623-647 in T. A. Bookhout, editor. Research and management techniques for wildlife and habitats. The Wildlife Society, Bethesda, Maryland, USA.

Gilbert, D. W., D. R. Anderson, J. K. Ringelman, and M. R. Szymczak. 1996. Response of nesting ducks to habitat and management on the Monte Vista National Wildlife Refuge, Colorado. Wildlife Monographs 131.

Gorenzel, W.P., R. A. Ryder, and C.E. Braun. 1981. American Coot response to habitat change on a Colorado marsh. Southwest Naturalist 26:59-65. http://dx.doi.org/10.2307/3671331

Gorenzel, W.P., R. A. Ryder, and C. E. Braun. 1982. Reproduction and nest site characteristics of American Coots at different altitudes in Colorado. Condor 84:59-65. http://dx.doi.org/10.2307/1367822

Grant, T. A., E. M. Madden, T. L. Shaffer, P. J. Pietz, G. B. Berky, and N. J. Kadrmas. 2006. Nest survival of Clay-colored and Vesper Sparrows in relation to woodland edge in mixed-grass prairies. Journal of Wildlife Management 70:691-701. http://dx.doi.org /10.2193/0022-541X(2006)70[691:NSOCAV]2.0.CO;2

Higgins, K. F., L. M. Kirsch, and I. J. Ball, Jr. 1969. A cable-chain device for locating duck nests. Journal of Wildlife Management 33:1009-1011. htt p://dx.doi.org/10.2307/3799339

Jobin, B., and J. Picman. 1997. Factors affecting marsh predation on artificial nests in marshes. Journal of Wildlife Management 61:792-800. http:/ /dx.doi.org/10.2307/3802186 
Jordan, T. E., and D. F. Whigham. 1988. The importance of standing dead shoots of the narrow leaved cattail, Typha angustifolia L. Aquatic Botany 29:319-328. http://dx.doi.org/10.1016/0304-3770(88) 90076-9

Joyner, D. E. 1977. Nest desertion by Ruddy Ducks in Utah. Bird Banding 48:19-24. http://dx.doi.org/1 $\underline{0.2307 / 4512288}$

Kantrud, H. K. 1985. Effects of vegetation manipulation on breeding waterfowl in prairie wetlands - a literature review. Fish and Wildlife Technical Report 3, U.S. Fish and Wildlife Service, Washington, D.C., USA.

Klett, A. T., H. F. Duebbert, C. A. Faanes, and K. F. Higgins. 1986. Techniques for studying nest success of ducks in upland habitats in the Prairie Pothole Region.. U.S. Fish and Wildlife Service Resource Publication 158, U.S. Fish and Wildlife Service, Washington, D.C., USA.

Krapu, G. L., L. G. Talent, and T. J. Dwyer. 1979. Marsh nesting by mallards. Wildlife Society Bulletin 7:104-110.

Lindvall, M. L., and J. B. Low. 1982. Nesting ecology and production of Western Grebes at Bear River Migratory Bird Refuge, Utah. Condor 84:66-70. http://dx.doi.org/10.2307/1367823

Maxson, S. J., and M. R. Riggs. 1996. Habitat use and nesting success of overwater nesting ducks in westcentral Minnesota. Journal of Wildlife Management 80:108-119. http://dx.doi.org/10.2307 $\underline{13802045}$

Middleton, B. 1998. Wetland restoration, flood pulsing, and disturbance dynamics. John Wiley \& Sons, New York, New York, USA.

Pieron, M. R., and F. C. Rohwer. 2010. Effects of large-scale predator reduction on nest success of upland nesting ducks. Journal of Wildlife Management 74:124-132. http://dx.doi.org/10.2193 12009-056

Sargeant, A. B., and P. M. Arnold. 1984. Predator management for ducks on waterfowl production areas in the northern plains. Vertebrate Pest Conference 11:161-167.
SAS Institute Inc. 2007. SAS OnlineDoc® 9.2. SAS Institute Inc., Cary, North Carolina, USA.

Shaffer, T. L. 2004. A unified approach to analyzing nest success. Auk 121:526-540. http://dx.doi.org/10 .1642/0004-8038(2004)121[0526:AUATAN]2.0.CO;2

Shaffer, T. L., and F. R. Thompson, III. 2007. Making meaningful estimates of nest survival with model-based methods. Studies in Avian Biology 34:84-95.

Sutherland, J. M. 1991. Effects of drought on American Coot, Fulica americana, reproduction in Saskatchewan Parklands. Canadian Field-Naturalist 105:267-273.

Sutherland, J. M., and W. J. Maher. 1987. Nest-site selection of the American Coot in the Aspen Parklands of Saskatchewan. Condor 89:804-810. http://dx.doi.org/10.2307/1368528

Weller, M. W., and C. E. Spatcher. 1965. Role of habitat in the distribution and abundance of marsh birds. Iowa State University of Science and Technology, Agriculture and Home Economics Experiment Station Special Report 43, Ames, Iowa, USA.

Westerkov, K. 1950. Methods for determining the age of game bird eggs. Journal of Wildlife Management 14:56-67. http://dx.doi.org/10.2307/3 $\underline{795978}$

Wolf, K. 1955. Some effects of fluctuating and falling water levels on waterfowl production. Journal of Wildlife Management 19:13-23. http://dx .doi.org/10.2307/3797548 